\title{
The APSÛ method for process-based groundwater vulnerability assessment
}

\author{
lleana-Cristina Popescu ${ }^{1,2} \cdot$ Serge Brouyère ${ }^{1} \cdot$ Alain Dassargues $^{1}$
}

Received: 29 October 2018 / Accepted: 25 June 2019

(C) Springer-Verlag GmbH Germany, part of Springer Nature 2019

\begin{abstract}
Groundwater vulnerability maps can be combined with pollution hazards to assess risks of groundwater pollution. However, groundwater vulnerability maps are generally difficult to interpret because they differ according to the factors considered and the way they are combined. Here, starting from process-based concepts and criteria, a robust definition for groundwater vulnerability to pollution is discussed. A methodology is developed based on processes governing the fate of pollutants at the land surface (i.e. runoff and infiltration) and below ground (i.e. pollutant transport in the subsurface). Groundwater vulnerability is evaluated based on combination of the land surface hazard and the subsurface attenuation capacity. Land surface hazard is defined to consider direct and lateral infiltration capacity of pollutants, regardless of any subsurface attenuation capacity, which refers to any process that leads to pollutant mass reduction from the infiltration location to the water table. The concept of subsurface attenuation capacity is adapted to the case of groundwater intrinsic vulnerability assessment, considering three process-based vulnerability coefficients, which are the pollutant minimum travel time from the hazard location to the water table, the pollution duration at the water table, and the maximum concentration of pollutant discharging into the groundwater. The concepts are illustrated by applying the developed method (named APSÛ) for intrinsic groundwater vulnerability assessment in the Néblon catchment, a karstified limestone/sandstone aquifer system in Belgium. The APSU method results are discussed and the perspectives for generalizing the method to groundwater-specific vulnerability and risk mapping are presented.
\end{abstract}

Keywords Vulnerability mapping $\cdot$ Land surface hazard $\cdot$ Infiltration and runoff $\cdot$ Subsurface attenuation capacity $\cdot$ Solute transport

\section{Introduction}

Groundwater represents an important component of the water cycle. In many places, it constitutes the most valuable resource for drinking water if not the only water resource available throughout the year. Especially in the dry season, it also plays a significant role in sustaining base flow to surface water and related ecosystems (Bredehoeft 1997; Hayashi and Rosenberry 2002; Boulton 2005). Owing to its location below

Serge Brouyère

Serge.Brouyere@uliege.be

1 Hydrogeology and Environmental Geology, Urban \& Environmental Engineering, University of Liège, Liège, Belgium

2 Groundwater Direction, Department of Environment \& Water, Public Authority of Wallonia, DGARNE-DGO3, Jambes, Belgium ground surface, groundwater is usually well protected from contamination originating from the land surface. However, water generally flows at very low velocity in the subsurface as compared to surface water, typically from a few centimeters to a few meters per day. Consequently, when pollutants infiltrate into the unsaturated zone and further propagate in the saturated groundwater zone, any remediation measure aimed at reducing concentrations may require long time spans and significant effort, particularly with persistent pollutants that are not degraded in the subsurface (Lapworth et al. 2015; Sorensen et al. 2015). Because of the difficulty in removing them from the subsurface, it is crucial to prevent as much as possible any groundwater quality degradation by taking appropriate measures to minimize such hazards.

Legal frameworks have been established in many countries and methodologies and tools have been developed and proposed to groundwater managers in order to prevent and to minimize the risk of groundwater pollution. Most often, 
preventive measures consist of defining protection zones around groundwater pumping wells or springs (e.g. USEPA 1993; Derouane and Dassargues 1998; Lallemand-Barres and Roux 1999; Wheater et al. 2000; Thomsen and Thorling 2003; Molson and Frind 2012). In these zones, human activities are regulated or restricted in order to minimize any risk of contamination. Most often, the limits of the protection zones are established by estimating pollutant travel times (e.g. in Belgium: $24 \mathrm{~h}$ and 50 days isochrones) in the saturated groundwater zone, from any location in the aquifer to the groundwater abstraction point. Implicitly, they are based on the minimum time needed for performing urgent remediation operations if contamination occurs in the protection zone, but they only provide short- to medium-term protection of groundwater. Furthermore, protection zones focus on abstraction points only (source protection) without contributing to sustainable groundwater quality in the whole basin (resource protection). They do not give any insight into estimating the natural protection and attenuation capacity of the unsaturated zone with regard to possible uncontrolled or unknown contamination issues. And finally, protection zones do not adequately address the problem of diffuse pollution for which the concept of travel time to the groundwater abstraction point is nonunique and ambiguous. An optimal and efficient groundwater protection methodology should thus consider water from the time it infiltrates the subsurface until it discharges in streams, lakes or springs or until it is extracted by pumping wells.

In this context, the concept of groundwater vulnerability or groundwater susceptibility to pollution is often considered to estimate the natural protective capacity or, on the other hand, the sensitivity of the subsurface to contamination (e.g. Albinet and Margat 1970; Tripet et al. 1997; Troiano et al. 2000; Focazio et al. 2002; Arthur et al. 2007).

Numerous groundwater vulnerability and risk mapping techniques have been developed taking into consideration a variable number of physical factors such as depth to groundwater, hydraulic conductivity, porosity and soil type, which are likely to increase or decrease the risk of groundwater contamination (e.g. Aller et al. 1987; Foster 1987; Doerfliger 1996; Doerfliger et al. 1999 ; Civita and De Maio 1997; von Hoyer and Söfner 1998; Goldscheider et al. 2000). The most common techniques are based on the calculation of an index expressing the protective effect of subsurface formations overlying the groundwater resource. The considered factors are mapped in the groundwater basin and overlaid using geographic information system (GIS) applications to produce groundwater vulnerability maps (Gogu and Dassargues 2000). Such maps can then be combined with information on potential contamination sources and associated hazards to produce groundwater contamination risk maps. Such methods are relatively easy to implement (Neukum et al. 2008) and they usually require little data; however, they produce results that are difficult to validate and to interpret because the resulting groundwater vulnerability maps can be very different according to the factors considered and the way they are combined (Gogu et al. 2003, Shrestha et al. 2017). The limitation of such methods is mostly related to their use of a qualitative definition of groundwater vulnerability, as opposed to a definition based on a quantitative description of pollutant migration (Brouyère et al. 2001; Popescu et al. 2004; Perrin et al. 2004; Popescu et al. 2008; Focazio et al. 2002; Arauzo 2017) which, in a more consistent way, allows to classify different sectors of the investigated catchment with respect to the type of consequences of a pollution event that could occur in that basin.

The fuzzy character of the concept of vulnerability is also exacerbated by the fact that the term "vulnerability" is used, and thus defined, in quite different policy contexts (e.g. Brooks 2003; Luers et al. 2003; Füssel 2007). As an example, in the European Union legislation, the Nitrate Directive (EC 1991; Goodchild 1998) has led to the definition of "groundwater zones vulnerable to nitrate" for areas which are the most exposed to nitrate regardless of the sensitivity of the groundwater system. The Water Framework Directive 2000/60/EC and the Groundwater Daughter Directive to WFD 2006/118/ EC (EC 2000, 2006; Nieto et al. 2005) require evaluation of groundwater vulnerability at the scale of the groundwater body without clearly defining in which way. However, as pointed out by Frind et al. (2006), groundwater sensitivity or groundwater susceptibility to contamination is most often addressed when referring to groundwater vulnerability.

The COST 620 European expert group adopted a common approach for assessing and mapping groundwater vulnerability (Daly et al. 2002; Zwahlen 2003; Andreo et al. 2006). The 'European approach' is based on the 'hazard-pathway-target' model and it distinguishes between 'resource vulnerability', which applies to the groundwater resource as a whole, and 'source vulnerability' which focuses on abstraction points such as pumping wells or springs, with particular attention paid to carbonate and karstic aquifers. 'Intrinsic vulnerability' is here defined as the groundwater vulnerability to pollutants, considering the inherent geological, hydrological, and hydrogeological characteristics, but independent of the nature of the pollutants (and so regardless of their specific physico-chemical properties). 'Specific vulnerability' additionally considers the chemical behaviour of the pollutants, such as sorption, degradation and transformation reactions, to estimate groundwater vulnerability to a specific pollutant or to a group of pollutants. The entire risk assessment procedure can then be considered (Brouyère et al. 2001) as a hierarchical process starting with intrinsic vulnerability, then 
progressing to specific vulnerability, and finally to risk assessment when combined with hazards (i.e. potential pollution at the land surface). In this framework, Brouyère et al. (2001) also proposed and discussed in detail a process-based point of view and definition of the concept of vulnerability, considering three factors describing a pollution event, which are the pollutant travel time from the hazard location to the target, the contamination duration at the target and the level of concentration reached by the pollutant at the target. These concepts were used in different groundwater vulnerability assessment studies (e.g. Frind et al. 2006; Butscher and Huggenberger 2009; Neukum and Azzam 2009; Graf 2015; Huan et al. 2016).

In this general context, the objective of the paper is to reframe the different concepts of groundwater vulnerability, starting from adequate, process-based concepts. In a second step, a general methodology is proposed for groundwater vulnerability assessment based on the definitions proposed. Finally, the presented concepts are illustrated using the APSU method developed for intrinsic vulnerability assessment applicable to different hydrogeological contexts, including karstic environments.

At this step, only a deterministic approach is considered. Next development steps could be to address uncertainties placing this methodology in a probability risk assessment (PRA) framework as developed, among others, by Tartakovsky (2007 and 2013).

\section{A revisited framework for groundwater vulnerability assessment}

The conceptual model on which this framework is based is as follows. The pollution hazard is supposed to occur on the land surface (buried pollution sources are not considered in the current approach) and pollutants emitted from the source are dissolved in the aqueous phase. Water is thus the main driver for the mobility of dissolved pollutants on land, by runoff and in the subsurface where infiltration is assumed to occur along the vertical direction (no lateral flow considered in the unsaturated zone).

From a very general point of view, one can define that groundwater is more sensitive or vulnerable if it is more likely to be polluted, in other words, if the quantity of pollutant that is likely to reach groundwater (resource vulnerability) and to propagate through it (source vulnerability) is larger (Brouyère et al. 2007). This is the case if pollutants emitted at the land surface are likely to travel across the soil and the unsaturated zone to reach, in significant quantity, i.e. at concentrations exceeding groundwater $(\mathrm{GW})$ quality standards, the water table and subsequently through the groundwater body to reach downgradient receptors such as pumping wells, springs or draining rivers (Fig. 1). In other words, if $0 \%$ of the emitted quantity of pollutant is able to reach the water table, the groundwater resource is not vulnerable at all. In contrast, if $100 \%$ of the pollutant reaches the water table, groundwater is extremely vulnerable.

Following this conceptual model, a logical expression for groundwater vulnerability is given by the relative quantity of emitted pollutant that can reach the considered groundwater target (Eq. 1).

$V=\frac{M_{\mathrm{GW}}}{M_{\text {Hazard }}}$

with $M_{\mathrm{GW}}=$ the quantity (mass) of pollutant reaching the groundwater (GW) target, $M_{\text {Hazard }}=$ the quantity (mass) of pollutant released from the hazard location (pollution source).

According to this general definition, groundwater is more vulnerable if pollutants can be transported from the hazard location at the land surface to the groundwater target (e.g. infiltrating water for dissolved pollutants and/or suspended matter for sorbing hazardous compounds) and if these pollutants are sufficiently conservative (e.g. low sorption or degradation) to reach groundwater at concentrations on the order of environmental norms. Groundwater vulnerability factors have to reflect, as much as possible, the capacity of the subsurface medium to naturally reduce the pollution intensity, and the processes that lead to pollutant mass reduction from hazard location to groundwater target (along the pathway). This includes two main categories of processes: (1) pollutant runoff out of the groundwater catchment, and (2) pollutant retardation and degradation processes along the pathways in the soil, subsoil and groundwater. Considering this conceptual model, the APSU method developed herein is based on two key components: 'land surface hazard' (LH) and 'subsurface attenuation capacity'.

\section{Land surface hazard}

When contamination occurs at some location within a groundwater catchment, the LH of that given location is defined here as being the maximum potential risk of groundwater pollution, regardless of any attenuation capacity of the subsurface environment. As the pollution (hazard) occurs, a fraction of the pollutant infiltrates locally (pollutant pathway P1D in Fig. 1). The remaining quantity of pollutant runs off laterally, following the local topography. During this travel, the pollutant may progressively infiltrate laterally (pathway P1L in Fig. 1) or may runoff further until it infiltrates in low topography locations - e.g. sinkholes, topographic depressionsor until the catchment outlet is reached. The LH 


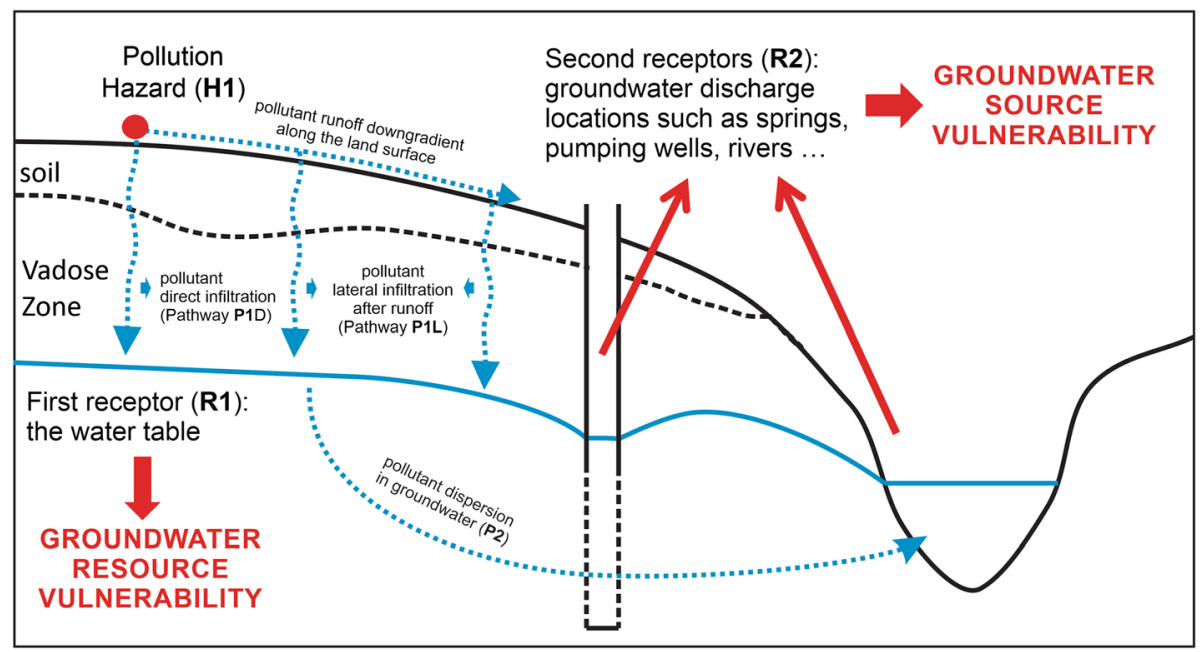

Fig. 1 Schematic representation of the hazard-pathway-target concept underlining the evaluation of groundwater vulnerability (adapted from Brouyère et al. 2007). Pollutants emitted at any location on the land surface (hazard location H1) can infiltrate through the soil and the unsaturated zone either directly (pathway P1D) or indirectly along their runoff pathway on the land surface (pathway P1L) to reach the water table

concept is thus intimately related to hydrologic conditions, infiltration and runoff, prevailing at the land surface of the groundwater catchment. If the pollutant does not infiltrate anywhere-e.g. low permeability soils or impervious lands - there is no danger for groundwater, at least in the studied catchment. In contrast, if most of the emitted pollutant infiltrates into the subsurface of the groundwater catchment, there is 'potentially' a danger for groundwater if there is no pollutant attenuation along its pathway to the groundwater target in the subsurface. Because it is related to the spatial distribution of infiltration conditions, LH depends on topography, soil properties and land use. One can also make a distinction between the direct land surface hazard (DLH) corresponding to the relative quantity of pollutant that infiltrates directly at the hazard location, and the lateral land surface hazard (LLH) corresponding to the quantity of pollutant that infiltrates laterally and progressively along its runoff pathway on the land surface. All these concepts will be developed further.

\section{Subsurface attenuation capacity}

As it reflects possible pollutant mass losses by sorption and degradation, the general definition of groundwater vulnerability proposed here (Eq. 1) is perfectly suited for specific groundwater vulnerability assessment. However, it does not hold directly for groundwater intrinsic vulnerability assessment. The latter should only reflect natural factors-i.e. geological, hydrological and hydrogeological conditions - contributing to a theoretical groundwater vulnerability to any kind of pollutants, e.g.
(Target 1: GW 'resource' vulnerability). Subsequently, pollutants can migrate through the groundwater body (pathway P2) to reach downgradient targets such as pumping wells, springs or draining rivers (Target 2: GW 'source' vulnerability). The APSÛ method focuses on groundwater resource intrinsic vulnerability assessment

degrading or not, thus not considering the specific properties of the pollutants such as specific degradation or sorption of the considered pollutant. Regardless of the land surface hazard, from an intrinsic point of view, if no degradation or sorption is considered, groundwater is always significantly vulnerable. In other words, groundwater intrinsic vulnerability would depend only on the relative quantity of infiltrating water at the land surface. This is an option, but it completely disregards the impact of physical processes such as hydrodynamic dispersion (mechanical dispersion and diffusion) and physical retardation in the subsurface that, at least, often contribute to delaying, dispersing, diluting and thus physically attenuating pollutants during the migration from the pollution source to the groundwater target. In particular, longer travel times often favour degradation of nonconservative pollutants and stronger pollution dispersion leading to concentration reduction at the groundwater target. Taking this into consideration, and following the proposition of Brouyère et al. (2001) and Popescu et al. (2004), the intrinsic attenuation capacity of the subsurface should contribute to answering the following questions: (1) When the pollutant infiltrates, how long does it take to reach the $\mathrm{GW}$ target (travel time)? (2) What is the expected maximum pollutant concentration at the GW target (pollution level)? (3) How long does it take to dissipate the pollution at the GW target (pollution duration)?

There are now three ways of quantifying groundwater vulnerability. Groundwater is more vulnerable when (1) the travel time between the hazard location and the groundwater target is short, (2) the pollution level at 
the groundwater target is high or (3) the pollution duration at the groundwater target is long.

For assessing groundwater resource intrinsic vulnerability, the vertical propagation of a pollutant pulse through the soil and geological layers in the unsaturated zone is considered. The pollutant of concern is assumed conservative, so is not affected by specific processes such as degradation or chemical reactions. The equation describing the vertical unidimensional propagation of a dissolved conservative pollutant in a porous medium is the advection-dispersion equation (Eq. 2).

$\frac{\partial c}{\partial t}=\frac{\partial}{\partial z}\left(D \frac{\partial c}{\partial z}\right)-v_{\mathrm{e}} \frac{\partial c}{\partial z}$

with $z$ being travel distance along the pollutant pathway[L], $t$ time $[\mathrm{T}], v_{\mathrm{e}}$ effective (transport) velocity $\left[\mathrm{LT}^{-1}\right], c$ pollutant concentration $\left[\mathrm{ML}^{-3}\right], D$ hydrodynamic dispersion coefficient $\left[\mathrm{L}^{2} \mathrm{~T}^{-1}\right]$.

The APSÛ method described hereafter is based on all these general concepts. APSÛ stands for Aquifer Protection by evaluating its Sensitivity vUlnerability. In the old Akkadian language, Apsî (or Abzu in Sumerian) was the name for the primeval sea below the void space of the underworld and the earth above. It may also refer to freshwater from underground aquifers that was given a religious fertilizing quality. Lakes, springs, rivers, wells, and other sources of fresh water were thought to draw their water from the Apsû.

\section{Description of the APSÛ method for intrinsic vulnerability assessment}

The basic concepts on which the APSÛ intrinsic vulnerability assessment method relies are relatively simple; however, the physical processes on which these concepts are based are potentially very complex (i.e. infiltration-runoff at the land surface, flow and pollutant transport in the soil and deeper vadose zone) and can require sophisticated modelling tools. The objective here is to obtain a representative image of the behaviour of pollutants in the subsurface, in a simplified but not simplistic manner, using an approach that remains flexible and easy to implement. The different steps addressed to elaborate the groundwater intrinsic vulnerability map are described in detail hereafter.

\section{Delineation and discretization of the groundwater catchment}

The APSÛ method can be applied at different scales, from local aquifers and river catchments to regional aquifer systems and large river basins. The surface flow component included in the approach requires however extending the investigated domain to hydrological limits such as topographic divides.
The first step is to delineate as accurately as possible the catchment of the groundwater resource of interest, which corresponds to all locations at the land surface from where water may reach the groundwater target either by direct infiltration or lateral infiltration after runoff on the land surface. This means clearly that the groundwater catchment can differ from the hydrogeological basin. The vulnerability assessment and mapping of the groundwater resource is then carried out on the basis of a regular grid (square mesh) corresponding to the delineated catchment (Fig. 2a).

\section{Evaluation of direct and lateral hazard coefficients}

Direct and LLH coefficients are computed using the following step-by-step procedure. Let a unit quantity (pulse) of water and pollutant be released at a location $i$ (cell $i$ from the two-dimensional (2D) discretization) at the land surface within the catchment (Fig. 2b). According to hydrological conditions prevailing at that location, a proportion $\mathrm{CI}_{i}$ of water and pollutant infiltrates directly. The DLH at location $i$ is thus defined here as the proportion of water and pollutant that infiltrates at location $i$ :

$\mathrm{DLH}_{i}=\mathrm{CI}_{\mathrm{i}}$

The remaining quantity, $\mathrm{CR}_{i}=1-\mathrm{CI}_{i}$, runs off downslope and may progressively infiltrate along the land surface pollutant pathway from $i$ (further called $\eta_{i}$ ). The LLH associated with location $i\left(\mathrm{LLH}_{i}\right)$ is thus proportional to $\mathrm{CR}_{i}$, but its magnitude and spatial distribution depend on infiltration conditions along $\eta_{i}$.

In any location $j$, downgradient from $i$, the lateral hazard $\mathrm{LLH}_{i}^{j}$ depends on:

1. The quantity of pollutant leaving $i$ by runoff, i.e. $\mathrm{CR}_{i}$

2. What is "lost along the way" by infiltration in the intermediate cells located between $i$ and $j$

3. The infiltration capacity at $j$, i.e. $\mathrm{CR}_{j}$

Considering this simplified representation of hydrological processes prevailing at the land surface using infiltration and runoff coefficients, one can show that the hazard coefficients associated with each cell $i$ of the catchment grid can be calculated as follows (Table 1).

The hazard coefficients are calculated as follows. First, in each cell of the catchment grid, infiltration and runoff coefficients are defined using runoff coefficients (Ebener 2000, adjusted from Mallants and Feyen 1990) based on (1) soil properties, (2) land use and (3) land slope (Table 2). Second, the land surface pollutant pathway $\eta_{i}$ corresponding to the cells located downslope from cell $i$ is determined using a 
Fig. 2 a A grid is mapped over the catchment as a basis for all calculations performed for groundwater vulnerability mapping. In each cell, a unit quantity of pollutant is assumed to be released. The pollutant can run off the catchment (hazard location 1 and land surface pathway $\eta_{1}$ ) or it may run off until it comes to a topographic depression such as a sinkhole where it may infiltrate in a concentrated manner (hazard location 2 and land surface pathway $\eta_{2}$ ). Each cell $j$ is also characterized by its drainage basin $\mathrm{DB}_{j}$. b Cross-section along the land surface pollutant pathway of cell $i$, showing the different coefficients used to calculate the hazard terms listed in Table 1

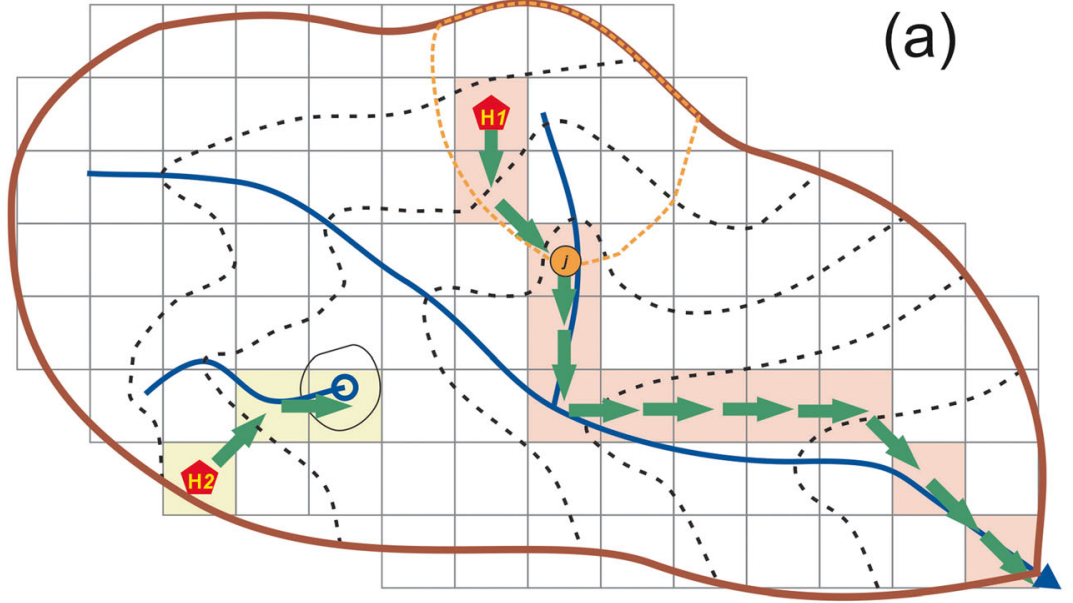

\section{Legend}
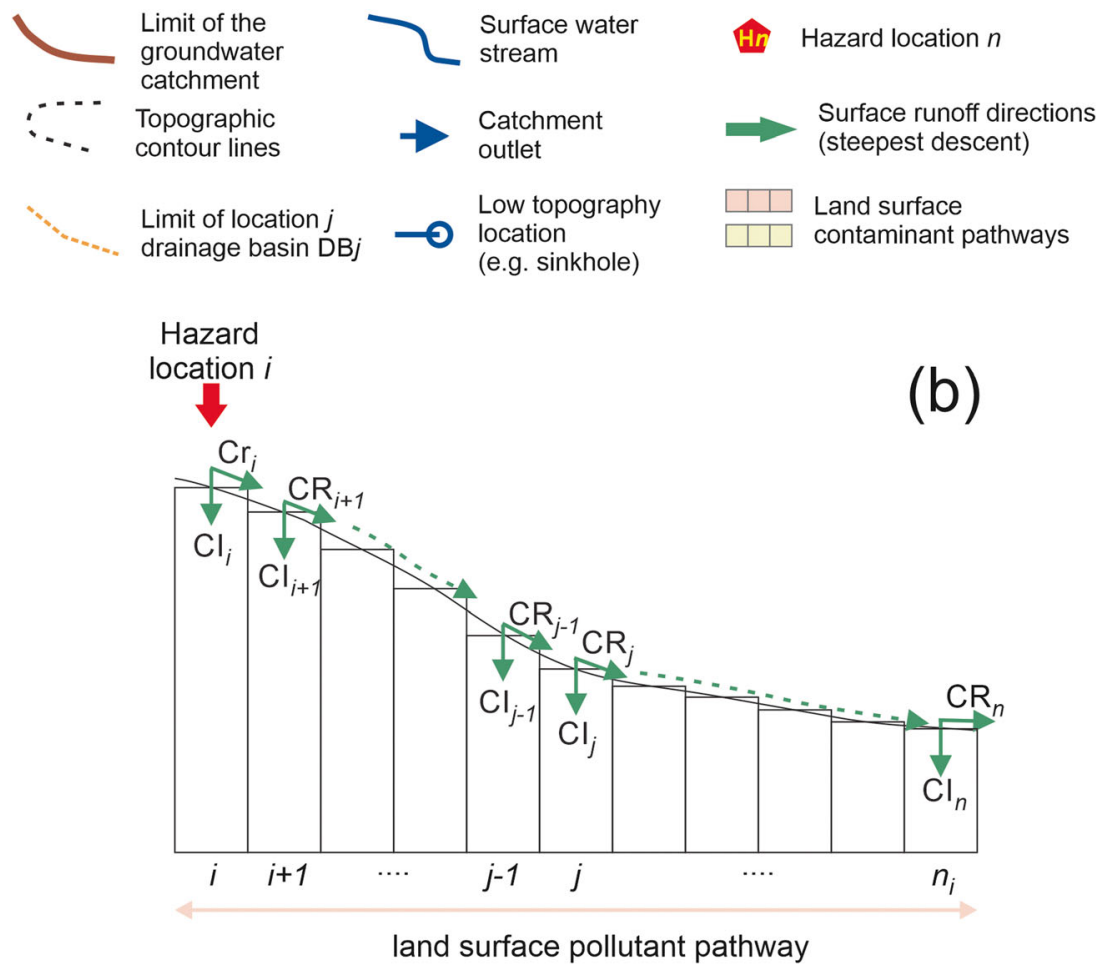

steepest descent algorithm based on a digital elevation model projected on the catchment grid. Third, for each cell $i$, the different LH coefficients are calculated along $\eta_{i}$ using Eqs. (4)-(8) listed in Table 1.

\section{Calculation of the subsurface attenuation capacity}

For assessing the intrinsic attenuation capacity of the subsurface, the one-dimensional (1D) vertical transport of a pollutant is calculated between the land surface (hazard location) and the water table, taking into account the nature and the thickness of different geological layers (Fig. 3). The response can be obtained with the help of a 1D advection-dispersion model. Since intrinsic vulnerability does not account for any specific pollution scenario, a Dirac-type unit mass of pollutant is considered as an input in the transport model. The general procedure is as follows. The groundwater catchment is discretized in the $(\mathrm{x}, \mathrm{y})$ plane, using the same grid as for the LH quantification. In each cell of the grid, the geology is vertically represented by a series of layers from land surface to water table: soil, sub-soil, unsaturated geological layers. Each column is composed of as many compartments as successive geological layers encountered along the vertical direction. Each compartment is characterised by its thickness and a 
Table 1 Mathematical expressions of the different land surface hazard (LH) terms. The land surface pollutant pathway $\eta_{i}$ is made of $n_{i}$ cells. The direct land surface hazard (DLH) (Eq. 4) reflects the immediate (local) risk of pollutant infiltration in the subsurface. The total lateral hazard (TLH; Eq. 7) reflects the importance of pollutant infiltration along the runoff pathway on the land surface. The cumulated lateral hazard $(C L H)$ in cell $j$ (Eq. 8) reflects the sensitivity of location $j$ to any pollution that could appear up-gradient in its drainage basin $\left(\mathrm{DB}_{j}\right) . L H$ lateral hazard; $L L H$ lateral land surface hazard

\begin{tabular}{|c|c|c|}
\hline Hazard term & Definition & Equation \\
\hline DLH of cell $i$ & $\mathrm{DLH}_{i}=\mathrm{CI}_{i}=1-\mathrm{CR}_{i}$ & Eq. (4) \\
\hline LLH of cell $i$ in cell $j$ located in $\eta_{i}$ & $\mathrm{LLH}_{i}^{j}=\prod_{k=i}^{j-1} \mathrm{CR}_{k} \times\left(1-\mathrm{CR}_{j}\right)$ & Eq. (5) \\
\hline LH of cell $i$ in $\eta_{i}$ & $\mathrm{LLH}_{i}=\sum_{k=i}^{\eta_{i}} \mathrm{LLH}_{i}^{k}=\mathrm{CR}_{i}-\prod_{k=i}^{\eta_{i}} \mathrm{CR}_{k}$ & Eq. (6) \\
\hline TLH of cell $i$ & $\mathrm{TLH}_{i}=\mathrm{DLH}_{i}+\mathrm{LLH}_{i}=1-\prod_{k=i}^{\eta_{i}}$ & Eq. (7) \\
\hline CLH of cell $j$ & $\mathrm{CLH}_{j}=\sum_{k=i}^{\mathrm{DB}_{j}} \mathrm{LLH}_{k}^{j}$ & Eq. (8) \\
\hline
\end{tabular}

material that reflects its lithology. A list of reference lithologies is established to which hydrodynamic and hydrodispersive properties are associated (i.e. hydraulic conductivity, effective transport porosity, longitudinal dispersivity) as necessary for transport calculations.

In most unstructured soils and geological porous media (i.e. with no preferential flow), the driver for the vertical flow of pollutant is gravity and is controlled by the effective infiltration rate $\left(I_{\mathrm{eff}}\right)\left[\mathrm{LT}^{-1}\right]$. In this case, the advective flux across the compartment is equal to the infiltration rate divided by the mobile water content $n_{\mathrm{e}}\left(\mathrm{L}^{3} \mathrm{~L}^{-3}\right)$.

$v_{\mathrm{e}}=\frac{I_{\mathrm{eff}}}{n_{\mathrm{e}}}$

The effective infiltration can be estimated based on a hydrological water budget over the catchment. This water budget should allow calculating a mean (annual) 'effective water' (EW) corresponding to water that is

Table 2 Values for the runoff coefficients (CR) used in APSÛ (Ebener 2000, adjusted from Mallants and Feyen 1990)

\begin{tabular}{|c|c|c|c|c|c|c|c|c|c|c|c|c|c|c|c|}
\hline \multirow{2}{*}{$\begin{array}{l}\text { Land } \\
\text { use }\end{array}$} & \multirow{2}{*}{$\begin{array}{l}\text { Slope } \\
\text { class }\end{array}$} & \multicolumn{14}{|c|}{ Soil type } \\
\hline & & $\begin{array}{l}\text { No } \\
\text { soil }\end{array}$ & Sand & $\begin{array}{l}\text { Loamy } \\
\text { sand }\end{array}$ & $\begin{array}{l}\text { Sandy } \\
\text { loam }\end{array}$ & $\begin{array}{l}\text { Silty } \\
\text { loam }\end{array}$ & Silt & Loam & $\begin{array}{l}\text { Sandy } \\
\text { clay } \\
\text { loam }\end{array}$ & $\begin{array}{l}\text { Silty } \\
\text { clay } \\
\text { loam }\end{array}$ & $\begin{array}{l}\text { Clay } \\
\text { loam }\end{array}$ & $\begin{array}{l}\text { Sandy } \\
\text { clay }\end{array}$ & $\begin{array}{l}\text { Silty } \\
\text { clay }\end{array}$ & Clay & Impervious \\
\hline \multirow[t]{4}{*}{ Forest } & $<0.5$ & 0.00 & 0.03 & 0.07 & 0.10 & 0.13 & 0.17 & 0.20 & 0.23 & 0.27 & 0.30 & 0.33 & 0.37 & 0.40 & 1.00 \\
\hline & $0.5-5.0$ & 0.00 & 0.12 & 0.13 & 0.15 & 0.17 & 0.19 & 0.22 & 0.25 & 0.28 & 0.32 & 0.36 & 0.40 & 0.45 & 1.00 \\
\hline & $5.0-10$ & 0.00 & 0.28 & 0.26 & 0.25 & 0.25 & 0.25 & 0.27 & 0.29 & 0.32 & 0.35 & 0.39 & 0.44 & 0.50 & 1.00 \\
\hline & $>10$ & 0.00 & 0.23 & 0.27 & 0.30 & 0.33 & 0.37 & 0.40 & 0.43 & 0.47 & 0.50 & 0.53 & 0.57 & 0.60 & 1.00 \\
\hline \multirow[t]{4}{*}{ Grass } & $<0.5$ & 0.00 & 0.03 & 0.07 & 0.10 & 0.13 & 0.17 & 0.20 & 0.23 & 0.27 & 0.30 & 0.33 & 0.37 & 0.40 & 1.00 \\
\hline & $0.5-5.0$ & 0.00 & 0.07 & 0.09 & 0.12 & 0.15 & 0.18 & 0.21 & 0.24 & 0.28 & 0.32 & 0.36 & 0.40 & 0.45 & 1.00 \\
\hline & $5.0-10$ & 0.00 & 0.15 & 0.15 & 0.16 & 0.18 & 0.20 & 0.23 & 0.27 & 0.31 & 0.36 & 0.42 & 0.48 & 0.55 & 1.00 \\
\hline & $>10$ & 0.00 & 0.20 & 0.21 & 0.22 & 0.24 & 0.26 & 0.29 & 0.33 & 0.37 & 0.42 & 0.47 & 0.53 & 0.60 & 1.00 \\
\hline \multirow[t]{4}{*}{ Crop } & $<0.5$ & 0.00 & 0.23 & 0.27 & 0.30 & 0.33 & 0.37 & 0.40 & 0.43 & 0.47 & 0.50 & 0.53 & 0.57 & 0.60 & 1.00 \\
\hline & $0.5-5.0$ & 0.00 & 0.27 & 0.31 & 0.34 & 0.37 & 0.41 & 0.44 & 0.47 & 0.51 & 0.54 & 0.57 & 0.61 & 0.64 & 1.00 \\
\hline & $5.0-10$ & 0.00 & 0.33 & 0.37 & 0.40 & 0.43 & 0.47 & 0.50 & 0.53 & 0.57 & 0.60 & 0.63 & 0.67 & 0.70 & 1.00 \\
\hline & $>10$ & 0.00 & 0.45 & 0.49 & 0.52 & 0.55 & 0.59 & 0.62 & 0.65 & 0.69 & 0.72 & 0.75 & 0.79 & 0.82 & 1.00 \\
\hline \multirow{4}{*}{$\begin{array}{l}\text { Bare } \\
\text { soil }\end{array}$} & $<0.5$ & 0.00 & 0.33 & 0.37 & 0.40 & 0.43 & 0.47 & 0.50 & 0.53 & 0.57 & 0.60 & 0.63 & 0.67 & 0.70 & 1.00 \\
\hline & $0.5-5.0$ & 0.00 & 0.37 & 0.41 & 0.44 & 0.47 & 0.51 & 0.54 & 0.57 & 0.61 & 0.64 & 0.67 & 0.71 & 0.74 & 1.00 \\
\hline & $5.0-10$ & 0.00 & 0.43 & 0.47 & 0.50 & 0.53 & 0.57 & 0.60 & 0.63 & 0.67 & 0.70 & 0.73 & 0.77 & 0.80 & 1.00 \\
\hline & $>10$ & 0.00 & 0.55 & 0.59 & 0.62 & 0.65 & 0.69 & 0.72 & 0.75 & 0.79 & 0.82 & 0.85 & 0.89 & 0.92 & 1.00 \\
\hline
\end{tabular}




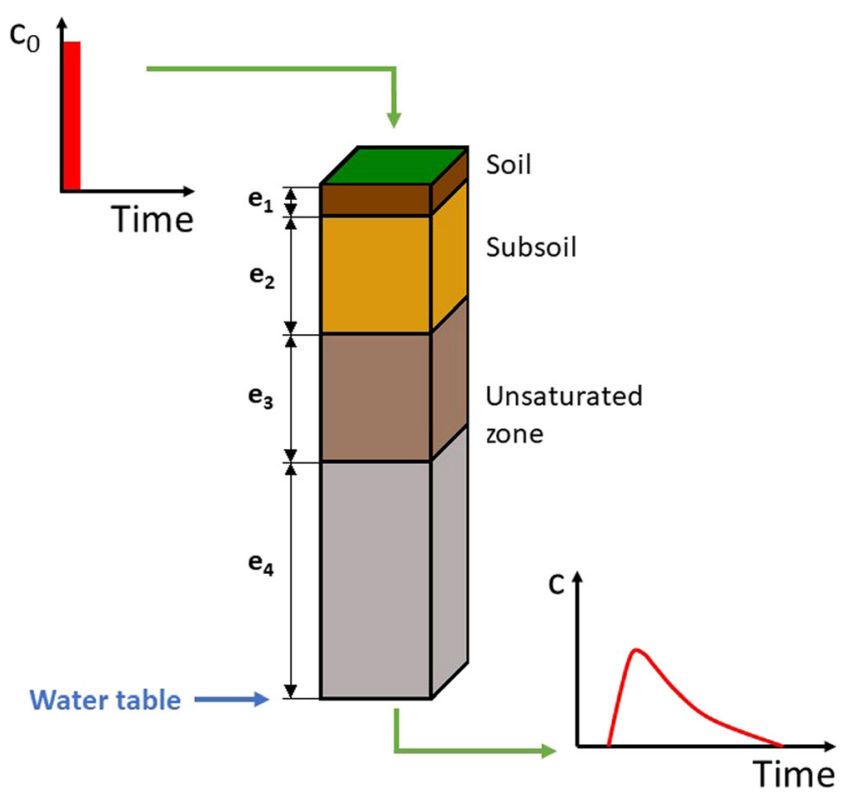

Fig. 3 Schematic calculated breakthrough curves showing the effect of each layer on 1D vertical solute transport (after Dassargues and Popescu 2003, Popescu et al. 2008)

available at the land surface for infiltration and runoff $(\mathrm{EW}=$ precipitation - evapotranspiration $)$. On a cell-bycell basis, the effective infiltration can be estimated as follows (in cell $i$ ):

$I_{\text {eff }}^{i}=\mathrm{EW} \times \mathrm{CI}_{i}$

In specific contexts such as outcropping fractured rocks or macro-porous soils (i.e. without any significant protective soil cover), during heavy rains, preferential flow may occur, which causes a possible by-pass of pollutants from the land surface to the water table, making groundwater strongly sensitive to pollution. For sectors of the groundwater catchment where preferential infiltration is assumed, the calculation method of the advection velocity within a compartment is calculated as follows:

$v_{\mathrm{e}}=\frac{K}{n_{\mathrm{e}}} \frac{\Delta h}{L}$

where $K$ is the saturated hydraulic conductivity of the soil or geological layer $\left[\mathrm{LT}^{-1}\right]$ and $\Delta h$ is the assumed pounding depth [L] developing at the land surface during heavy rain (arbitrarily set by the user, usually a few millimeters) and $L$ is the thickness of the layer.

In each column of the grid, the advective-dispersive transport of a pulse of pollutant (Dirac type) is calculated using the analytical solution of van Genuchten and Wierenga (1976) for solute transport in 1D steady-state variably saturated single- or dual-domain flow fields. Here, the single-domain (advection-dispersion) solution available in the CXTFIT code (Toride et al. 1995) was used. This allows calculating, in each cell $i$ of the catchment, the pollutant breakthrough at the water table and determining the expected pollutant travel time $t_{i}$ from the land surface to the water table, and the pollution duration $d_{i}$ and level $c_{i}^{\max }$ at the base of the unsaturated zone.

\section{Real hazard: vulnerability}

Following the first two steps of the procedure, in each cell $i$ of the grid, different $\mathrm{LH}\left(\mathrm{DLH}_{i}, \mathrm{LLH}_{i} \ldots\right)$ and subsurface attenuation coefficients $\left(t_{i}, d_{i}, c_{i}^{\max }\right)$ are available. If cell $i$ is located upgradient from any sensitive location $j$ in $\eta_{i}$ (i.e. high infiltration and low subsurface attenuation capacity at $j$ ), the combination of LH and attenuation capacity coefficients must classify location $i$ as vulnerable, regardless of the infiltration and attenuation capacity determined in cell $i$. This is obtained by weighting the three attenuation coefficients by the hazard coefficients, at the scale of the land surface pollutant pathway $\eta_{i}$ as follows:

$$
\begin{gathered}
\hat{t}_{i}=\mathrm{DLH}_{i} \times t_{i}+\sum_{j \subset \eta_{i}} \mathrm{LLH}_{i}^{j} \times t_{j} \\
\hat{d}_{i}=\mathrm{DLH}_{i} \times d_{i}+\sum_{j \subset \eta_{i}} \mathrm{LLH}_{i}^{j} \times d_{j} \\
\hat{c}_{i}^{\max }=\mathrm{DLH}_{i} \times c_{i}^{\max }+\sum_{j \subset \eta_{i}} \mathrm{LLH}_{i}^{j} \times c_{j}^{\max }
\end{gathered}
$$

Thus, for each point in the groundwater catchment, the weighted pollutant travel time $\hat{t}_{i}$, duration $\hat{d}_{i}$ and maximum concentration $\hat{c}_{i}^{\max }$ are obtained.

\section{The final vulnerability map}

For visualizing and mapping values obtained for the three vulnerability criteria-weighted travel time, duration and concentration level - classes can be conventionally chosen on iso-contour maps. This choice must be established in consultation with groundwater managers and decision makers (Dassargues et al. 2009). Considering each criterion apart, three distinct vulnerability maps can be obtained. These maps reflect, in a clear process-based and understandable way, different possible interpretations of the concept of groundwater intrinsic vulnerability. Of course, these three criteria are related (i.e. short travel times usually correspond to higher maximum concentrations).

Beside these thematic maps, a "unique" integrated groundwater vulnerability map can be produced, as done with other "classical" groundwater vulnerability methods, using a multi-criteria analysis. This requires 
that each vulnerability factor is subdivided into the same number of classes. The final vulnerability index may be calculated as follows:

$V=\alpha \times V_{\mathrm{t}}+\beta \times V_{\mathrm{c}^{*}}+\gamma \times V_{\mathrm{d}}$

with $\alpha, \beta$ and $\gamma$ established by multi-criteria decisionaid, with the constraint:

$\alpha+\beta+\gamma=1$

\section{Practical implementation of the APSÛ method}

From a practical point of view, the information on topography, climate, land use, soil, geology and piezometry forms the basis of the layers prepared under a GIS environment. The current approach uses predefined values for all the soil and hydrogeological parameters without considering the uncertainty and variability that may affect all these properties in reality. The APSÛ method thus produces "deterministic" groundwater vulnerability maps. A set of Fortran 90 subroutines has been developed and compiled into an 'APSÛ executable file' (Windows OS). The APSÛ executable reads all the layers of information produced with the GIS and calculates the different hazard and vulnerability coefficients to produce a set of maps, including the "final vulnerability map" (for availability of this executable, contact the corresponding author).

\section{Application to a test basin: the NEBLON carboniferous aquifer (Belgium)}

The test area consists of a slightly karstified groundwater catchment area located in the Condroz region (Belgium), $30 \mathrm{~km}$ southwest of the city of Liège (Fig. 4). The basin covers about $65 \mathrm{~km}^{2}$ and is a part of the Néblon River basin (DGARNE 2010). This test area was previously chosen by Gogu et al. (2003) for comparing results from six groundwater vulnerability methods: EPIK (Doerfliger 1996), GOD (Foster 1987), ISIS (Civita and De Regibus 1995), DRASTIC (Aller et al. 1987), the German method (von Hoyer and Söfner 1998) and PI (Goldscheider et al. 2000).

\section{Geological and hydrogeological context}

The Néblon basin (Fig. 4) is on the eastern part of the Dinant synclinorium, which is characterized by a typical alternation of shale and sandstone anticlinal ridges (Famennian-Upper Devonian) and calcareous synclinal depressions (DinantianLower Carboniferous). Folds and faults affect these formations (LGIH, 1986; Di Clemente and Laurent 1986; Dreze 1997; Boulvain 2006; Robert and Nguyen 2007; and Barchy and Marion 2008 and 2018). Locally, paleokarsts developed in limestone have been subsequently filled with Tertiary deposits, whereas Quaternary silts cover the whole region.

The hydrologic network is asymmetrical, more developed on the right bank of the Néblon River, in the southern part of the area, where many springs flow from Famennian formations. This part of the basin is characterised by more permanent streams and more significant runoff, related to the shale and sandstone substratum and steep slopes, and north oriented. The main aquifer corresponds to fissured and locally karstified Dinantian limestones. It is drained from NE to SW, owing to the structural saddle. There is a high diversity of piezometer behaviour, due to aquifer heterogeneity. Seasonal fluctuations of piezometric levels are observed (between 5 and $40 \mathrm{~m}$; Hallet et al. 2000, Popescu et al. 2004, Brouyère et al. 2009, Ruthy et al. 2016). The natural outflows of the aquifer are diffuse discharges in the Néblon River and a major group of springs at Néblon-le-Moulin. These springs have been exploited for more than a century via four drainage galleries by the CILE Water Company, abstracting between 25,000 and $30,000 \mathrm{~m}^{3}$ day $^{-1}$. Other aquifers are located in Upper Famennian fissured and altered sandstone anticlines. Groundwater in these aquifers, generally perched, flows towards nearby limestone depressions, through faults or via surface waters. There are also temporary or permanent springs, which occur on low permeability shale formations (a part of Lower Dinantian). Shale sandstone Namurian formations, located in the middle of synclines, constitute perched, fractured aquifers of small capacity. Groundwater in these unconfined aquifers also flows towards the limestone aquifers in the faulted zones or by overflow springs (depending on presence of shales). Tertiary and Quaternary formations present a low hydrogeological interest. The heterogeneous Tertiary deposits have a limited extension and poor aquifer capacities. The silt layer, several meters thick, has however a good filtration capacity with respect to meteoric water and also introduces a delay in the recharge of aquifers. Hydrogeological balance applied to the Néblon catchment indicates that water exchange with adjacent basins is very limited (Brouyère et al. 2009).

The area does not show a high degree of karstification (youth stage, drainage network not very structured; Meus 1993) even if several karstic features are reported: the Néblon-le-Moulin springs, swallow-holes, diffuse infiltration areas, dry valleys, some dolines and caves of limited extension CWEPSS 1996). Tracer tests highlighted groundwater conduit flows between one of the main swallow-holes and the Néblonle-Moulin galleries.

\section{Data input (coverages)}

Groundwater vulnerability mapping of the Néblon limestone aquifer is based on a grid made of $30 \mathrm{~m} \times 30 \mathrm{~m}$ cells. As 


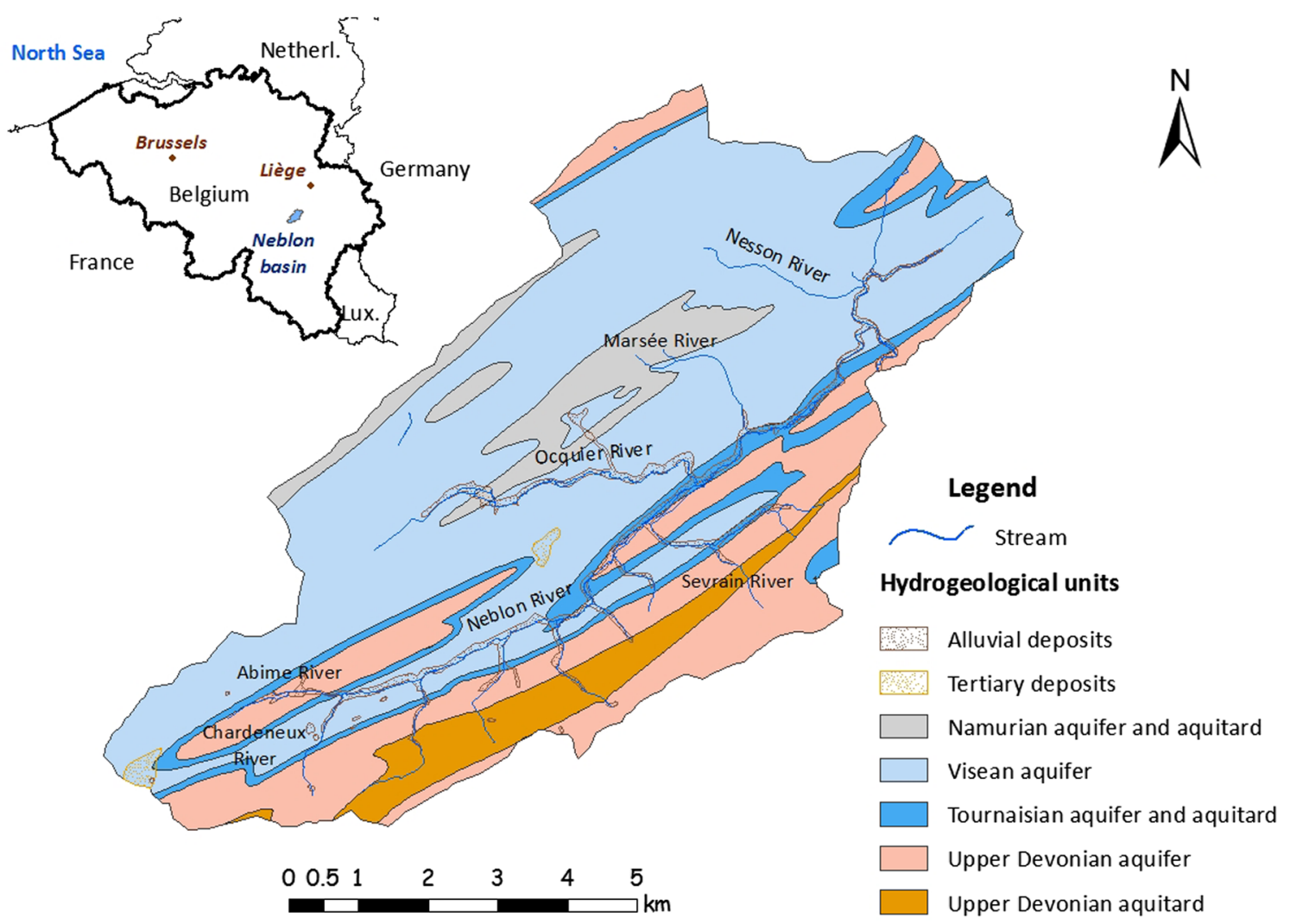

Fig. 4 Geological map of the Néblon basin

mentioned previously, different cartographic data are needed for groundwater intrinsic vulnerability assessment. The six starting coverages are: a digital elevation model of Belgium on 1:50000 scale, IGN, 1980), the CORINE land use and land cover map (1990), a soil map (CNSW 2002), the Walloon geological and hydrogeological maps (Barchy and Marion 2018; Hallet et al. 2000; Ruthy et al. 2016) and a piezometric map drawn in March 2003 (Popescu et al. 2004). Finally, water surplus (i.e. water available for infiltration and runoff after subtracting real evapotranspiration and soil-water storage capacity from rainfall) was calculated based on rainfall and temperature data available at a meteorological station at Ouffet, located just north of the Néblon basin.

\section{Calculation of LH coefficients}

Calculation of LH coefficients in each cell $i$ are calculated using ArcView (Spatial Analyst/3D Analyst extensions). Cell slopes are calculated from the DEM and then classified according to the values indicated in Table $2(<0.5,0.5-5,5-$ $10,>10)$ to produce a slope classes map. Land surface pollutant pathways are obtained by identifying downslope cells based on surface flow directions. Infiltration and runoff coefficients $\mathrm{CI}_{i}$ and $\mathrm{CR}_{i}$ are obtained by the combination of the slope classes, soil and land cover maps (Table 2).

The resulting LLH map is presented in Fig. 5. This shows that areas characterised by maximum LLH values correspond to impervious zones, often urban sectors (where direct hazard is zero). In areas where soils are absent or preferential infiltration is established (e.g. near sinkholes), the lateral hazard is zero (water completely infiltrate locally, with no runoff). Generally, lateral hazard is more important in areas with shale and sandstone substratum (south-east of the Néblon basin). On limestone, slopes are generally lower.

\section{Calculation of subsurface attenuation capacity coefficients}

Based on an extensive data inventory (Popescu et al. 2004), a description of each 1D column from the land surface to the water table was obtained. The piezometric map was obtained based on groundwater levels measured in the basin, considering high groundwater-level conditions as worst-case conditions, i.e. reduced thickness of a protective unsaturated zone cover.

Each cell of the 2D horizontal grid is thus associated with a vertical column made of different layers, most often the soil layer and one or two deeper layers corresponding to different geological horizons in the unsaturated zone. Each layer is associated with a material identifier. Each material is in turn associated with values of saturated hydraulic conductivity, effective transport porosity and a dispersivity to thickness ratio (to account for the fact that dispersivity is recognized as being scale dependent). The high vulnerability expected for 


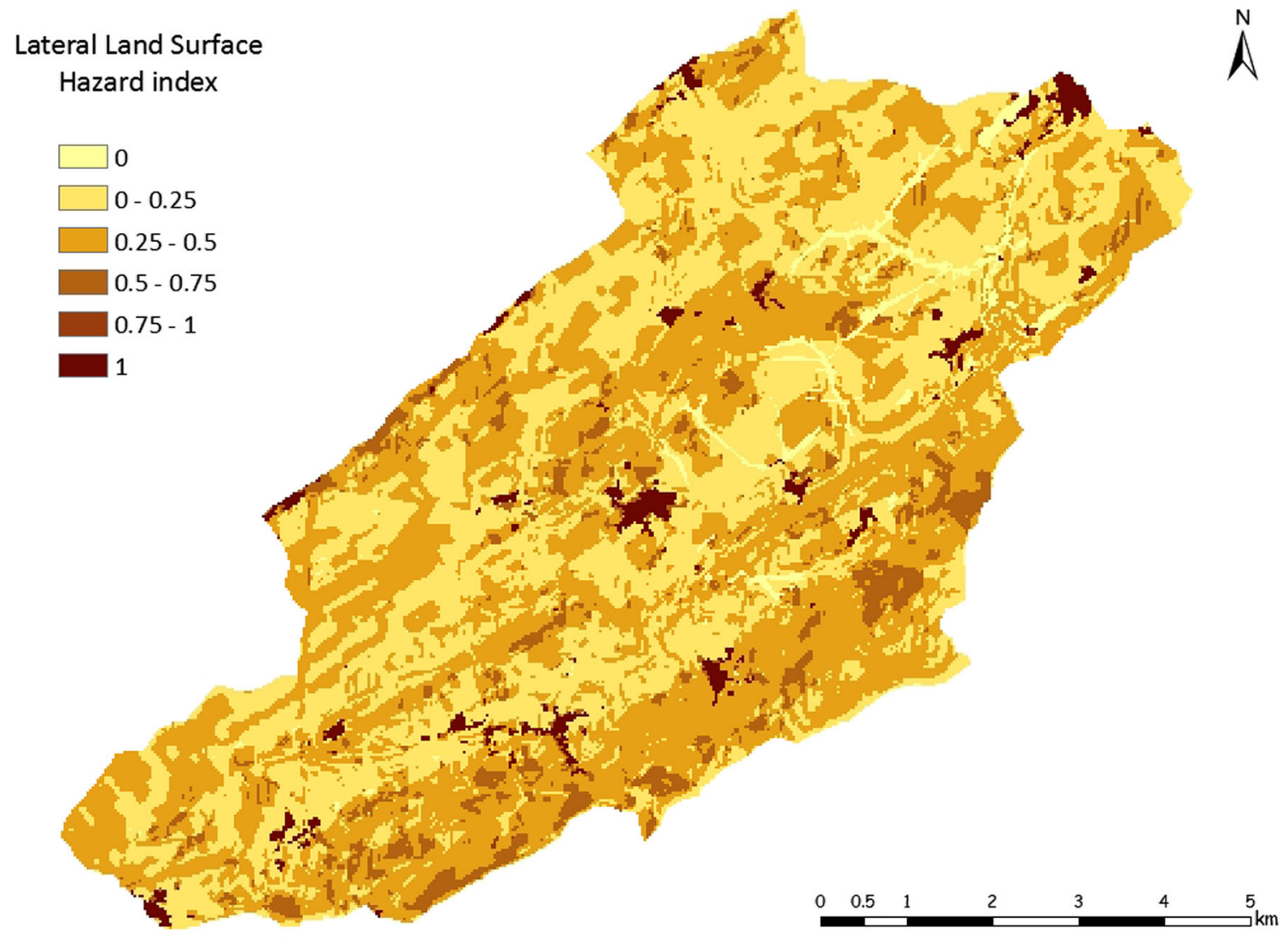

Fig. 5 Map of lateral land surface hazard (LLH) of the Néblon basin

karstic features such as sinkholes and dolines is considered by prescribing the cells where these features occur to be highly vulnerable. Solute transport simulations across the different geological layers assume an equivalent porous medium but the effect of rock fracturation (particularly in the limestone aquifers) is taken into account using larger dispersion coefficients and using the concept of preferential pathway (Eq. 11) where such rocks are outcropping and where they are overlain by macro-porous soils. Based on this geometrical discretization, subsurface attenuation coefficients are calculated by modelling the $1 \mathrm{D}$ transport of a unit quantity of pollutant across the different columns.

Figure 6 shows a map of the classified pollutant minimum travel times from land surface to the water table. This map refers to a "direct" vulnerability assessment, without considering the LH. By weighting the vulnerability criteria (travel time, duration and attenuation in the unsaturated zone) by hazard coefficients, vulnerability maps related to each weighted criterion are obtained. Figure 7 shows the vulnerability map related to the weighted minimum travel time criteria.

In areas with shale and sandstone bedrock, the vulnerability is moderate to low (moderate zones are dominant), whereas in limestone aquifers, results are more contrasted. Low vulnerability is observed in areas where the thickness of the unsaturated zone is important, and the soil offers a good protection.
In contrast, very high vulnerability is obtained where groundwater is shallow, where limestone outcrops, or where karstic features such as sinkholes are present.

A comparison between Figs. 6 and 7 shows that, in the present context where infiltration often prevails locally over runoff, the influence of lateral hazard remains limited. However, a reduction of less vulnerable areas is systematically observed near urban areas and where less pervious soils prevail (over shale and sandstones, notably in the south-east part of the basin), to the benefit of more vulnerable areas, leading as expected to a general increase of groundwater vulnerability in the basin.

\section{Groundwater vulnerability maps}

Based on these results, different vulnerability maps can be drawn using different weighting coefficients $\alpha, \beta$ and $\gamma$ and Eqs. (15) and (16). Classical groundwater vulnerability assessment methods usually prescribe the weighting coefficients used to combine the different groundwater vulnerability factors into a final vulnerability index. From this study's point of view, the choice of these coefficients should be left to the decision of (or defined in agreement with) the local community, groundwater managers and decision makers (Dassargues et al. 2009). Many combinations can be considered depending 


\section{Minimum travel time}

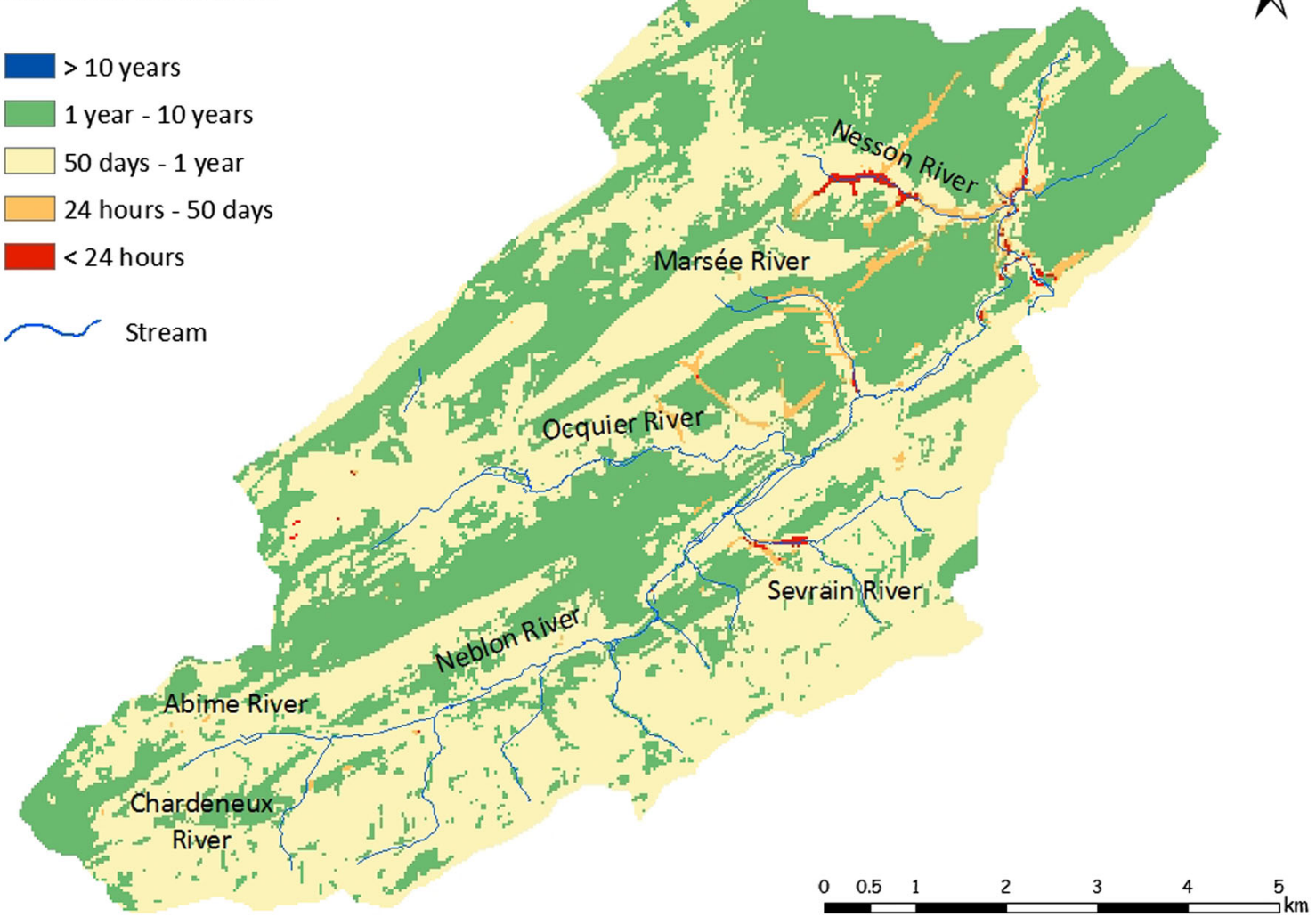

Fig. 6 Map of pollutant minimum travel times from the land surface to the water table

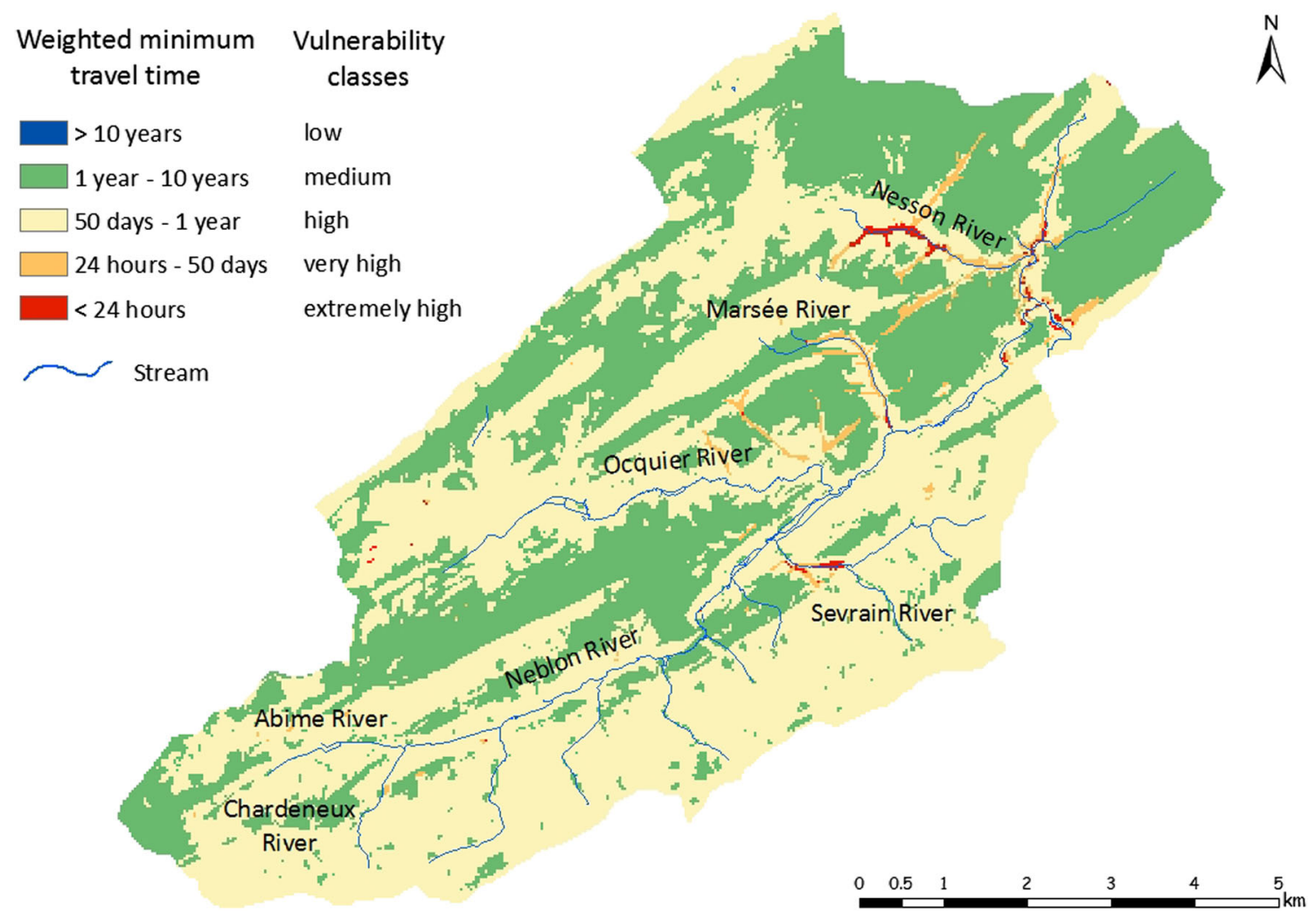

Fig. 7 Map of pollutant weighted minimum travel times from the land surface to the water table 
on the purpose of the investigated case. Among the three criteria considered in APSU, the (weighted) minimum travel time is certainly the most relevant for groundwater resource vulnerability assessment because time is the key driver in all the contaminant attenuation processes and in decision-making. The criterion on maximum concentration is useful to identify sectors were pollutant threshold values are more likely to be exceeded. And finally, the criterion on pollution duration is relevant for the manager of a groundwater catchment who is interested in knowing the length of time that the pollution will deteriorate groundwater quality in the investigated aquifer.

As an example, a vulnerability map is presented in Fig. 8 considering weighting coefficients of 0.45 for the minimum travel time coefficient, 0.45 for the pollution duration coefficient and 0.10 for the maximum concentration coefficient. Based on this classification, the Néblon basin can be classified as moderately (medium) to extremely (very high) vulnerable.

\section{Conclusions and perspectives}

After having discussed the limitations and drawbacks of most existing groundwater vulnerability assessment methods, a general discussion has been presented and a general framework proposed for process-based groundwater vulnerability assessment. A new methodology has been described for intrinsic groundwater vulnerability conforming to this general framework. The APSU method is fully compliant with the COST 620 European Approach and recommendations for groundwater vulnerability assessment (Daly et al. 2002; Zwahlen 2003) which is based on the hazard-pathway-target paradigm. Applying the LH concept, it naturally accounts for flow concentration on the land surface. Finally, the driving processes also accommodate the notion of relative quantity of contaminant that can reach the target. One of the key innovative aspects of the APSU method is the conceptualization of groundwater vulnerability as reflecting the combination of $\mathrm{LH}$ and subsurface attenuation capacity, and the introduction of the innovative concepts of LH coefficients.

The driving concept of the APSÛ method is to produce maps which are meaningful for decision-making, because they are essentially based on simple physical processes driving the fate of water and pollutants in the groundwater catchment. When existing methods were applied on the Néblon basin (Gogu et al. 2003), the resulting maps were very different in terms of patterns and colours, some of the methods classifying the basin as very vulnerable, others as less

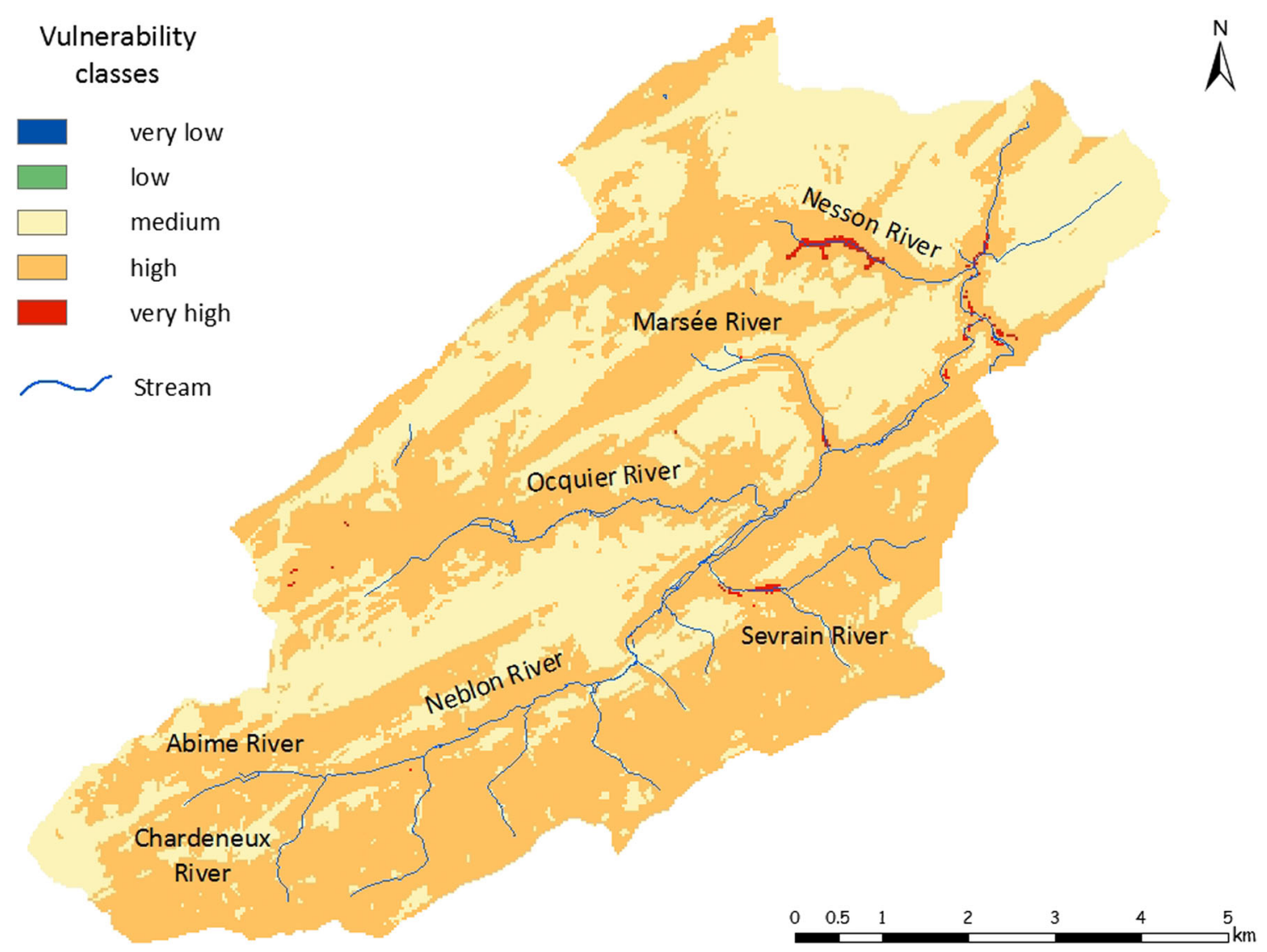

Fig. 8 Example of vulnerability map for the Néblon basin as obtained with weighting coefficients of $0.45,0.45$ and 0.10 respectively for the minimum travel time, pollution duration and maximum concentration vulnerability coefficients 
vulnerable. This reflects to some extent that the classification of groundwater vulnerability is somehow arbitrary in each method; however, there were also contradictory results between the different methods, with similar spatial sectors classified as highly vulnerable for some methods, less vulnerable for others. Generally speaking, the main conclusion of this comparison is that, from a practical and operational point of view, these vulnerability methods are difficult to use for decision making. Here, the APSU method also leads to colour patterns; however, they clearly reflect what one can expect from the pollutant behaviour in the subsurface based on the vulnerability coefficients on travel time, duration and concentration level. These thematic maps can of course also be combined by decision-makers into a final vulnerability map to reflect the relative importance they give to the different groundwater vulnerability coefficients. The innovative aspect here is the fact that this final step is not prescribed in the method and the user can perform different combinations considering different groundwater management objectives. Doing a more detailed comparison between the results obtained with the APSÛ method and results obtained with other methods is beyond the scope of this paper. At a first glance, it appears the APSÛ vulnerability map obtained considering the (weighted) travel times compares relatively well with the vulnerability map obtained with the PI method (Goldscheider et al. 2000), except in the south of the Néblon basin where APSÛ classifies the Devonian aquifers as more vulnerable compared to PI. For the final vulnerability map presented here above, no evident comparison can be made; however, this is logical and expected because this final map is based on a relatively arbitrary weighted combination of the different physically-based factors.

Up to now, the field of application of the APSÛ method is groundwater intrinsic vulnerability assessment, considering that the pollutants are conservative (no sorption, no degradation). Here, the method is illustrated for the Néblon basin which serves as a benchmark for such applications; however, the APSÛ method has already been applied in other geological contexts in Belgium and abroad. Recently, the APSÛ method has been applied in the whole Walloon Region $\left(16,850 \mathrm{~km}^{2}\right)$ at the scale of the defined 'groundwater bodies' as a support to reporting for the EU Water Framework Directive-River Basin Management Plans (Thomas et al. 2019).

Further ongoing steps will extend the APSÛ method to groundwater specific vulnerability assessment. Thanks to its process-based definition and the underlying mathematical formulation (i.e. pollutant transport in the subsurface), this extension is relatively straightforward as it "just" requires replacing the advective-dispersive solute transport equation in the subsurface by a more general transport equation handling sorption and degradation processes. For pollutants such as pesticides and other organic compounds, attenuation mechanisms mostly occur in the soil horizon, where most of the organic matter is concentrated and most (bio-)degradation processes occur.
Extending the APSÛ method to specific vulnerability assessment thus also requires obtaining a reliable representation and parametrization of the soil horizon. Recently, Bah (2014) worked on using the digital soil map of the Walloon region of Belgium to estimate pesticide leaching to groundwater. The approach proposed in this work could serve as a basis for groundwater specific vulnerability mapping and for developing similar approaches to other types of pollutants.

One of the next steps is also to develop a framework for the combination of the APSÛ method with risk mapping, by first combining the spatial pattern of the pollution scenario and associated probability of occurrence and the corresponding distribution of LH coefficients as an input for estimating the subsurface attenuation capacity. Given the number of pollution scenarios that could be considered such a probabilistic framework could be relatively complex. As mentioned by Tartakovsky (2013), a PRA framework facilitates a system's approach to risk quantification and management in complex multi-component, multi-physics systems. One possibility to be explored would thus consist of incorporating the APSU approach into a PRA framework, by formulating a fault tree analysis (Tartakovsky 2007) based on the APSÛ methodology. In particular, formulating a "system failure" based on the APSÛ concepts and criteria should be relatively straightforward. Using a PRA framework would also allow one to account for the uncertainties and spatial variability of the different land surface and subsurface parameters (heterogeneity in soil categories and hydrogeological parameters, occurrence of preferential pathways ...) to produce "probabilistic maps" of groundwater vulnerability and risk. In this context, the SERAN database (Briers et al. 2017) developed for the hydrogeological parameters of the main aquifers of the Walloon region of Belgium could serve as a basis for the quantification of uncertainty on hydrogeological parameters used in APSÛ.

Acknowledgements The authors would like to thank the reviewers for their enriching suggestions. We also thank M. John Molson for assistance with the English.

\section{References}

Albinet M, Margat J (1970) Cartographie de la vulnérabilité à la pollution des nappes d'eau souterraines [Mapping aquifer vulnerability to pollution]. Bull BRGM 2(3-4):13-22

Aller L, Bennett T, Lehr J, Petty R, Hackett G (1987) DRASTIC: a standardized system for evaluating ground water pollution potential using hydrogeologic settings. EPA-600/2-87-035. National Water Well Association, Ada, OK

Andreo B, Goldscheider N, Vadillo I, Vías JM, Neukum C, Sinreich M, Jiménez P, Brechenmacher J, Carrasco F, Hötzl H, Jesús Perles M, Zwahlen F (2006) Karst groundwater protection: first application of a pan-European approach to vulnerability, hazard and risk mapping in the Sierra de Líbar (southern Spain). Sci Total Environ 357(1-3): 54-73 
Arauzo M (2017) Vulnerability of groundwater resources to nitrate pollution: a simple and effective procedure for delimiting nitrate vulnerable zones. Sci Total Environ 575(1):799-812

Arthur JD, Wood HAR, Baker AE, Cichon JR, Raines GL (2007) Development and implementation of a Bayesian-based aquifer vulnerability assessment in Florida. Nat Resour Res 16(2):93-107. https://doi.org/10.1007/s11053-007-9038-5

Bah BB (20140 Valorisation de l'information pédologique numérisée pour la modélisation de la percolation des pesticides vers les eaux souterraines [Enhancement of the digitalized soil information for the modelling of pesticides percolating to groundwater]. $\mathrm{PhD}$ Thesis, University of Liège, The Netherlands. http://hdl.handle.net/2268/ 171835. Accessed June 2019

Barchy L, Marion JM (2008) Carte géologique de Maffe-Grandhan et sa notice explicative [Geological map of Maffe-Grandhan and its explanatory note]. Service Public de Wallonie, DGARNE, Namur, Belgium. http:/hdl.handle.net/2268/1659. Accessed June 2019

Barchy L, Marion JM (2018) Carte géologique de Wallonie à l'échelle 1/25000. Modave-Clavier no48/7-8 et sa notice explicative [Geological map of Wallonia at the scale 1/25000. ModaveClavier no. 48/7-8]. Service Public de Wallonie, DGARNE, Namur, Belgium. http://hdl.handle.net/2268/82915. Accessed June 2019

Boulton AJ (2005) Chances and challenges in the conservation of groundwaters and their dependent ecosystems. Aquat Conserv 15(4):319-323

Boulvain F (2006) Une introduction à la géologie de la Wallonie [An introduction to the geology of Wallonia]. Université de Liège, Faculté des Sciences, Département de Géologie. Cours en ligne, http://www.geolsed.ulg.ac.be/geolwal/geolwal.htm. Accessed June 2019

Bredehoeft JD (1997) Safe yield and the water budget myth. Ground Water 35(6):929

Briers P, Dollé F, Orban PH, Piront L Brouyère S (2017) Statistical description of hydrogeological parameters for the main aquifer contexts in Wallonia (in French). In: Etablissement des valeurs représentatives par type d'aquifère des paramètres hydrogéologiques intervenant dans l'evaluation des risques pour les eaux souterraines en application du Décret du 5 décembre 2008 relatif à la gestion des sols. GEOLYS final report. SPW/DGO3, University of Liège, Belgium

Brooks N (2003) Vulnerability, risk and adaptation: a conceptual framework. Working Paper 38. Tyndall Centre for Climate Change Research, Norwich, UK

Brouyère S, Jeannin PY, Dassargues A, Goldscheider N, Popescu IC, Sauter M, Vadillo I, Zwahlen F (2001) Evaluation and validation of vulnerability concepts using a physically based approach. In Mudry J, Zwahlen F (eds) Proc. of the 7th Conf. on Limestone Hydrology and Fissured Media. Mémoire no. 13, Sciences et Techniques de l'Environnement, Université de Franche-Comté, Besançon, France, pp 67-72

Brouyère $S$, Hérivaux $C$, Haberman $M$, Dassargues $A$, Dujardin $J$, Batelaan O, Canters, F, Crévecoeur S, Debacker V, Thomé J-P, Manshoven S (2007) Methodology for integration of process studies and development of a decision support tool. BELSPO FRACWECO Project Deliverable D1.2, 31 pp. http://hdl.handle.net/ 2268/188806. Accessed June 2019

Brouyère S, Gesels J, Goderniaux P, Jamin P, Robert T, Thomas L, Dassargues A, Bastien J, Van Wittenberge F, Rorive A, Dossin F, Lacour J-L, Le Madec D, Nogarède P, Hallet V (2009) Caractérisation hydrogéologique et support à la mise en œuvre de la Directive Européenne 2000/60 sur les masses d'eau souterraine en Région Wallonne (projet Synclin'EAU): Délivrable D.2.22 Rapport de caractérisation de masse d'eau souterraine, partie RWM021 [Hydrogeological characterization and support for the implementation of the European Directive 2000/60 on groundwater bodies in the Walloon Region (Synclin'EAU project): Deliverable D.2.22 Groundwater mass characterization report, part RWM021]. Convention RW et SPGE-Aquapôle. http://hdl.handle.net/2268/ 151991. Accessed June 2019

Butscher C, Huggenberger P (2009) Enhanced vulnerability assessment in karst areas by combining mapping with modeling approaches. Sci Total Environ 407(3):1153-1163

CNSW(2002) Carte numérique des sols de Wallonie) [Digital map of the soils of Wallonia] version 1. Faculté Universitaire des Sciences agronomiques de Gembloux - Laboratoire de Géopédologie, Gembloux, Belgium

CWEPSS (1996) Atlas du Karst Wallon: inventaire cartographique et descriptif des sites karstiques et rivières souterraines de Wallonie [Atlas Karst Wallon: cartographic and descriptive inventory of karstic sites and underground rivers of Wallonia]. DGARNE and CWEPSS. http://www.cwepss.org/atlasKarst.htm. Accessed June 2019

Civita, M, De Maio M (1997) SINTACS - Un sistema parametrico per la valutazione e la cartografia della vulnerabilità degli acquiferi all'inquinamento [SINTACS: a parametric system for assessing and mapping the vulnerability of aquifers to pollution]. In: Metodologia and automatizzazione. Quaderni di Tecniche di Protezione Ambientale 60]. Pittagora, Bologna, Italy, 208 pp

Civita M, De Regibus C (1995) Sperimentazione di alcune metodologie per la valutazione della vulnerabilità degli aquiferi [Experimentation of some methodologies for aquifer vulnerability assessment]. Quadern Geolog Applicata 3:63-71

Daly D, Dassargues A, Drew D, Dunne S, Goldscheider N, Neale S, Popescu CI, Zwahlen F (2002) Main concepts of the 'European approach' for (karst) groundwater vulnerability assessment and mapping. Hydrogeol J 10:340-345

Dassargues A, Popescu IC (2003) From data collection to map validation: analytical and numerical modelling. In: Vulnerability and risk mapping for the protection of carbonate (karst) aquifers. COST620 final report, EUR 20912 (Ed: Zwahlen F) pp 136-141. http://hdl.handle. net $/ 2268 / 3230$

Dassargues A, Popescu IC, Beaujean J, Lemieux, JM, Brouyère S (2009) Reframing groundwater vulnerability assessment for a better understanding between decision makers and hydrogeologists. In: The role of hydrology in water resources management (Proc. of IAHS IHP2008) Eds. H.J. Liebscher, R. Clarke, J. Rodda, G. Schultz, A. Schumann, L. Ubertini and G. Young, Capri, 13-16 October 2008, IAHS Press Publ. no. 327, pp 278-284

Derouane J, Dassargues A (1998) Delineation of groundwater protection zones based on tracer tests and transport modelling in alluvial sediments. Environ Geol 36(1-2):27-36

DGARNE, Direction des Eaux Souterraines (2010) Directive Cadre de l'eau: etat des lieux de la masse d'eau souterraine RWM021 « Calcaires et Grès du Condroz » [Water Framework Directive: state of the groundwater body RWM021 "Limestone and sandstone of Condroz"]. http://eau.wallonie.be/fme/RWM021.pdf. Accessed June 2019

Di Clemente C, Laurent S (1986) Contribution à l'étude hydrogéologique du bassin du Néblon. TLGIH. Université de Liège, Belgium

Doerfliger N (1996) Advances in karst groundwater protection strategy using artificial tracer tests analysis and multiattribute vulnerability mapping (EPIK method). PhD Thesis, Univ. Neuchâtel, Neuchâtel, Switzerland

Doerfliger N, Jeannin PY, Zwahlen F (1999) Water vulnerability assessment in karst environments a new method of defining protection areas using a multi-attribute approach and GIS tools (EPIK method). Environ Geol 39(2):165-176

Dreze M (1997) Contribution à l'étude hydrogéologique du bassin versant du Néblon. DESS en hydrologie. LGIH, Université de Liège, Belgique 
Ebener S (2000) Utilisation d'un SIG en mode raster pour la spatialisation du bilan hydrique à l'échelle mensuelle: application au bassin versant de l'Allendon (France, Suisse)[Use of a GIS in raster mode for the spatialization of the water balance on a monthly scale: application to the watershed of the Allendon (France, Switzerland)]. Terre and Environnement 20, PhD Thesis, University of Geneva (Switzerland), $268 \mathrm{pp}$

EC (1991) Council Directive 19/676/EEC of 12 December 1991 concerning the protection of waters against pollution caused by nitrates from agricultural sources. Official Journal L (375), EC, Brussels, $1 \mathrm{p}$

EC (2000) Water Framework Directive 2000/60/EC of the European Parliament and of the Council of 23 October 2000 establishing a framework for Community action in the field of water policy (ECJ 22 December 2000). EC, Brussels

EC (2006) Directive 2006/118/EC of the European Parliament and of the Council of 12 December 2006 on the protection of groundwater against pollution and deterioration" (Daughter to 2000/60/EC). EC, Brussels

European Union (1990) Corine land cover. European Environment Agency. http://land.copernicus.eu/pan-european/corine-land-cover/ clc-1990/view. Accessed June 2019

Focazio MJ, Reilly TE, Rupert MG, Helsel DR (2002) Assessing groundwater vulnerability to contamination: providing scientifically defensible information for decision makers. US Geol Surv Circ 1224

Foster S (1987) Fundamental concept in aquifer vulnerability pollution risk and protection strategy. Proc. Int. Conf. Vulnerability of soil and groundwater to pollution. Noordwijk, The Netherlands, April 1987

Frind EO, Molson JW, Rudolph DL (2006) Well vulnerability: a quantitative approach for source water protection. Ground Water 44(5): $732-742$

Füssel H-M (2007) Vulnerability: a generally applicable conceptual framework for climate change research. Glob Environ Chang 17: $155-167$

Gogu R, Dassargues A (2000) Current and future trends in groundwater vulnerability assessment using overlay and index methods. Environ Geol 39(6):549-559

Gogu R, Hallet V, Dassargues A (2003) Comparison between aquifer vulnerability assessment techniques: application to the Néblon River basin (Belgium). Environ Geol 44(8):881-892

Goldscheider N, Klute M, Sturm S, Hötzl H (2000) The PI method: a GISbased approach to mapping groundwater vulnerability with special consideration of karst aquifers. Z Angew Geol 46(3):157-166

Goodchild RG (1998) EU policies for the reduction of nitrogen in water: the example of the nitrates directive. Environ Pollut 102(S1):737-740

Graf T (2015) Physically-based assessment of intrinsic groundwater resource vulnerability. PhD Thesis, Univ. Laval, QB, Canada, 233 pp

Hallet V, Peters V, Ruthy I, Gogu RC, Monjoie A (2000) Carte hydrogéologique de Wallonie (prototype) [Hydrogeological map of Wallonia (prototype)]. Modave-Clavier, 48/7-8. 1:25000, Service Public de Wallonie, DGARNE, Namur, Belgium, 43 pp

Hayashi M, Rosenberry DO (2002) Effects of ground water exchange on the hydrology and ecology of surface water. Ground Water 40(3): 309-316

Huan H, Wang J, Zhai Y, Xi B, Li J, Li M (2016) Quantitative evaluation of specific vulnerability to nitrate for groundwater resource protection based on process-based simulation model. Sci Total Environ 550:768-784

Lallemand-Barres A, Roux JC (1999) Périmètres de protection des captages d'eau souterraine destinée à la consommation humaine [Perimeters for the protection of groundwater catchments intended for human consumption]. Manuel et Méthodes no. 33, BRGM, Orléans, France, 334 pp

Lapworth DJ, Baran N, Stuart ME, Manamsa K, Talbot J (2015) Persistent and emerging micro-organic contaminants in chalk groundwater of England and France. Environ Pollut 203:214-225
Luers AL, Lobel DB, Sklar LS, Addams CL, Matson PA (2003) A method for quantifying vulnerability applied to the agricultural system of the Yaqui Valley, Mexico. Glob Environ Chang 13(4):255-267

Mallants D, Feyen J (1990) Kwantitatieve en kwalitatieve aspecten van oppervlakte- en grondwaterstroming [Quantitative and qualitative aspects of surface and groundwater flow]. KUL, Leuven, Belgium

Meus PH (1993) Hydrogéologie d'un aquifère karstique du calcaire carbonifère en Belgique (Néblon - Anthisnes): apport des traçages à la connaissance des milieux fissurés et karstifiés [Hydrogeology of a karstic aquifer of Carboniferous limestone in Belgium (Néblon - Anthisnes): contribution of tracing to the knowledge of cracked and karstified environments]. PhD Thesis, University of Liège, Belgium

Molson JW, Frind EO (2012) On the use of mean groundwater age, life expectancy and capture probability for defining aquifer vulnerability and time-of-travel zones for source water protection. J Contam Hydrol 127(1-4):76-87

Nieto P, Custodio E, Manzano M (2005) Baseline groundwater quality: a European approach. Environ Sci Pol 8(4):399-409

Neukum C, Azzam R (2009) Quantitative assessment of intrinsic groundwater vulnerability to contamination using numerical simulations. Sci Total Environ 408(2):245-254

Neukum C, Hoetzl H, Himmelsbach T (2008) Validation of vulnerability mapping methods by field investigations and numerical modelling. Hydrogeol J 16(4):641-658

Perrin J, Pochon A, Jeannin P-Y, Zwahlen F (2004) Vulnerability assessment in karstic areas: validation by field experiments. Environ Geol 46(2):237-245

Popescu IC, Dachy M, Brouyère S, Dassargues A (2004) Tests d'une méthode de cartographie de la vulnérabilité intrinsèque applicable aux nappes aquifères de la Région Wallonne: application à l'aquifère calcaire du Hoyoux-Néblon [Test of an intrinsic vulnerability mapping technique for application to aquifers of the Walloon Region: application to the Hoyoux-Néblon limestone aquifer]. Report for DGRNE Walloon Region, Namur, Belgium

Popescu IC, Gardin N, Brouyère S, Dassargues A (2008) Groundwater vulnerability assessment using physically based modelling: from challenges to pragmatic solutions. In: Refsgaard JC et al (eds) Calibration and reliability in groundwater modelling: credibility in modelling. IAHS Publ. 320, IAHS, Wallingford, UK, pp 83-88

Rapport CILE - LGIH - INIEX (1986) Etude hydrogéologique du bassin versant du Néblon. LGIH, Université de Liège, Liege, Belgium

Robert T, Nguyen F (2007) Caractérisation hydrogéologique et support à la mise en œuvre de la Directive Européenne 2000/60 sur les masses d'eau souterraine en Région Wallonne (projet Synclin'EAU): rapport des prospections géophysiques [Hydrogeological characterization and support for the implementation of the European Directive $2000 / 60$ on groundwater bodies in the Walloon Region (Synclin'EAU project): report of geophysical surveys]. Convention RW et SPGE-Aquapôle, AGRIS, FAO, Rome

Ruthy I, Hallet V, Péters V, Gogu RC, Dassargues A, Monjoie A (2016) Carte hydrogéologique de Wallonie, Planchettes Modave-Clavier no. 48/7-8 [Hydrogeological map of Wallonia, Planchettes Modave-Clavier no. 48/7-8. Dépôt légal D/2016/12.796/4, Service Public de Wallonie, DGO 3 (DGARNE), Namur, Belgium

Shrestha S, Kafle R, Prasad Pandey V (2017) Evaluation of index-overlay methods for groundwater vulnerability and risk assessment in Kathmandu Valley, Nepal. Sci Total Environ 575:779-790

Sorensen JPR, Lapworth DJ, Nkhuwa DCW, Stuart ME, Gooddy DC, Bell RA, Chirwa M, Kabika J, Liemisa M, Chibesa M, Pedley S (2015) Emerging contaminants in urban groundwater sources in Africa. Water Res 72:51-63

Tartakovsky DM (2007) Probabilistic risk analysis in subsurface hydrology. Geophys Res Lett 34:L05404. https://doi.org/10.1029/ 2007GL029245 
Tartakovsky DM (2013) Assessment and management of risk in subsurface hydrology: a review. Adv Water Resour 51:247-260

Thomas C, Dollé F, Orban P, Dassargues A, Brouyère S 2019) Développement d'un module SIG de cartographie de la vulnérabilité des eaux souterraines et de risques et application aux principales masses d'eau souterraine de Wallonie. Délivrable D03: Description des applications réalisées et cartes de vulnérabilité produites avec l'outil SIG [Development of a GIS module for mapping the vulnerability of groundwater and risks and application to the main groundwater bodies of Wallonia. D03: Description of the applications made and vulnerability maps produced with the GIS tool]. http://hdl.handle.net/2268/225539. Accessed June 2019

Thomsen R, Thorling L (2003) Use of protection zones and land management to restore contaminated groundwater in Denmark. Eos Trans AGU 84(7):63-65

Toride N, Leij FFJ, van Genuchten MT (1995) The CXTFIT code for estimating transport parameters from laboratory or field tracer experiments, version 2.0, Research report no. 137, U.S. Salinity Laboratory, Riverside, CA, $121 \mathrm{pp}$

Tripet J-P, Doerfliger N, Zwahlen F (1997) Vulnerability mapping in karst areas and its uses in Switzerland. Hydrogéologie 3:51-57
Troiano J, Spurlock F, Marade J (2000) Update of the Californian Vulnerability soil analysis for movement of pesticides to ground water. 4 Oct. 1999. EH 00-05. Environmental Monitoring and Assessment Program, Dep. of Pesticide Regulation, California EPA, Sacramento.

USEPA (1993) Guidelines for delineation of wellhead protection areas. EPA-440/5-93-001, USEPA, Washington, DC

Van Genuchten MT, Wierenga PJ (1976) Mass transfer studies in sorbing porous media: I. analytical solutions. Soil Sci Soc Am J 40:473-480

von Hoyer M, Söfner B (1998) Groundwater vulnerability mapping in carbonate (karst) areas of Germany. Archiv no. 117854, Federal Institute for Geosciences and Natural Resources. Hanover, Germany, $38 \mathrm{pp}$

Wheater HS, Tompkins JA, van Leeuwen M, Butler AP (2000) Uncertainty in groundwater flow and transport modelling: a stochastic analysis of well-protection zones. Hydrol Process 14:2019-2029

Zwahlen F (ed) (2003) COST Action 620 vulnerability and risk mapping for the protection of carbonate (karst) aquifers: final report. European Cooperation in the Field of Scientific and Technical Research, Publication Office, Brussels, 297 pp 